\title{
ONLINE DISPUTE RESOLUTION AND JUSTICE SYSTEM INTEGRATION: BRITISH COLUMBIA'S CIVIL RESOLUTION TRIBUNAL
}

\author{
Shannon Salter*
}

This article undertakes a brief comparison of private and public online dispute resolution [ODR] systems before providing an overview of the Civil Resolution Tribunal [CRT], Canada's first online tribunal, and its ODR processes. The article discusses why the CRT has come to be, how it has been implemented, as well as its implications for civil justice reform more broadly. A main proposition is that the transformational potential of ODR will only be realized when ODR is fully integrated with public justice processes. This proposition is not without its difficulties, as the CRT's experience illustrates. To this end, the article also provides an introduction to some of the opportunities and challenges offered by an integrated ODR system like the CRT as well as some of the steps the CRT has taken to meet these demands as transparently and collaboratively as possible.

Dans cet article, l'auteure compare brièvement les systèmes privé et public de règlement des conflits en ligne (RCL) avant de donner un aperçu du Civil Resolution Tribunal (tribunal de règlement des conflits au civil (TRCC)), le premier tribunal en ligne du Canada, et des processus qui le régissent. L'article traite des raisons sous-jacentes à la création du TRCC, de la façon dont il a été mis sur pied ainsi que, de manière générale, de ses incidences sur la réforme du système de justice en matière civile. L'auteure soutient principalement que les possibilités de transformation du RCL passent impérativement par une intégration avec les processus de justice publique. Or, c'est là une démarche parsemée d'embûches, ainsi que l'illustre l'expérience du TRCC. Dans ce contexte, l'auteure fait état de quelques-uns des défis et des possibilités que comporte un régime RCL intégré comme celui du TRCC, ainsi que de certaines des mesures que celui-ci a prises pour relever ces défis de manière à favoriser le plus possible la transparence et la collaboration.

* Shannon Salter is the Chair of the Civil Resolution Tribunal. She earned her Bachelor of Arts (2001) and Bachelor of Laws (2005) from the University of British Columbia and her Master of Laws from the University of Toronto (2011). Salter clerked with the Supreme Court of British Columbia, practised litigation at a large Vancouver law firm for several years, and has served as a vice chair of the Workers' Compensation Appeal Tribunal. She is also a commissioner of the Financial Institutions Commission, vice president of the British Columbia Council of Administrative Tribunals, a board member of the Canadian Legal Information Institute (CanLII), and a past board member of the College of Registered Nurses of British Columbia. She is a co-author of the BC Administrative Decision Maker's Manual. 


\section{INTRODUCTION ${ }^{1}$}

Put the public first. This is the appeal from the Action Committee on Civil and Family Justice (Action Committee), led by Justice Thomas Cromwell, former justice of the Supreme Court of Canada. ${ }^{2}$ It is a deceptively simple concept, and one with which we, as lawyers, would intuitively agree. If there is a unifying theme in the legal profession, it is a common desire to help the clients we serve. However, we must also acknowledge that our profession resists change. Our common law tradition is built on the notion that precedent, or what came before, is inherently better and more trustworthy than some uncertain future innovation. This preference for past over present, while key to the development and refinement of the principles of justice that strengthen our legal system, has also become an impediment to adopting procedural changes to our legal system that would greatly improve access to justice for the public we are meant to serve.

Truly putting the public first in civil matters would require us to examine intensely the structure of our legal system and to ask ourselves, to whom does the justice system really belong? As the Action Committee's report argues, "court processes - language, location, operating times, administrative systems, paper and filing requirements, etc. - typically make sense and work for lawyers, judges and court staff. They often do not make sense or do not work for litigants." ${ }^{3}$ The Action Committee's report concludes that the civil and family justice system is too complex, slow, and expensive to produce "just outcomes that are proportional to the problems brought to it or reflective of the needs of the people it is meant to serve." 4

One of the promises of online dispute resolution [ODR], and technology generally, is that it will increase access to justice by removing barriers like cost, time, and information asymmetry. ${ }^{5}$ In doing so, it would offer an answer to the Action Committee's call to provide dispute resolution that is more proportional and tailored to the needs of the public. ODR has a wide definition and, as Richard Susskind points out, can include almost any dispute resolution process, including negotiation, mediation, facilitation, arbitration or other adjudication, so long as it is carried out online and outside a traditional physical setting. ${ }^{6}$ It can also include programs or systems offered by private enterprises, non-profit organizations, governments, or a combination of these.

In support of the idea that ODR can reduce barriers to public justice processes, proponents point to the near universality of Internet access in developed countries like Canada. ${ }^{7}$ They also argue that the public is overwhelmingly familiar with everyday online activities. Indeed, research in British Columbia shows

1 Portions of this article were drawn from papers originally presented at the Osgoode Forum on Administrative Law and Practice in Toronto on 23-24 October 2014 and the Continuing Legal Education Society of British Columbia's (CLEBC) Administrative Law Conference in Vancouver on 30 October 2014.

2 Action Committee on Access to Justice in Civil and Family Matters, "Access to Civil and Family Justice: A Roadmap for Change" (October 2013), online: <http://www.cfcj-fcjc.org/sites/default/files/docs/2013/AC_Report_English_Final.pdf> [Action Committee].

3 Ibid. at iii.

$4 \quad$ Ibid. at 7.

5 O Rabinovich-Einy, "Balancing the Scales: The Ford-Firestone Case, the Internet, and the Future Dispute Resolution Landscape" (2006) 6 Yale JL \& Tech 29.

6 Richard Susskind, "Foreward" in Mohamed S Abdel Wahab et al, eds, Online Dispute Resolution: Theory and Practice a Treatise on Technology and Dispute Resolution (The Hague, Netherlands: Eleven International Publishing, 2012).

7 Network BC Connectivity Map, online: BC Government

$<$ http://www2.gov.bc.ca/gov/topic.page?id=07995D6F9B7947E2AD602A101FBCAFA6>. 
people are comfortable with online banking, email, texting, and searching, for example. ${ }^{8}$ Conversely, despite the very high number of Canadian adults who experience serious, difficult-to-resolve legal issues, ${ }^{9}$ the public is overwhelmingly unfamiliar, and uncomfortable, with traditional justice processes, such as those that take place in courthouses, tribunals, and their registries. ${ }^{10}$ Evidence suggests that engaging with a civil justice process can wreak havoc on a person's mental, physical, and financial well-being. ${ }^{11}$ This, combined with the high cost of justice, discussed below, may explain why Canadians tend not to seek help for the vast majority of justiciable issues. ${ }^{12}$

The Civil Resolution Tribunal [CRT] is Canada's first online tribunal and, currently, the only ODR system in the world that is fully integrated into the justice system. The CRT allows the public to resolve their condominium property and small claims disputes fairly, quickly, and affordably. ${ }^{13}$ The CRT provides the public with access to interactive information pathways, tools, and a variety of dispute resolution methods including negotiation, facilitation and, if necessary, adjudication. ${ }^{14}$ Participants use all of these ODR services from a computer or mobile device at a time that is convenient for them. For those who are unable or unwilling to use technology to resolve their dispute, the tribunal provides paper-based or telephone-based services.

This article undertakes a brief comparison of private and public ODR systems before providing an overview of the CRT and its ODR processes. The article discusses why the CRT has come to be, how it has been implemented, as well as its implications for civil justice reform more broadly. A main proposition is that the transformational potential of ODR will only be realized when ODR is fully integrated with public justice processes. This proposition is not without its difficulties, as the CRT's experience illustrates. To this end, the article also provides an introduction to some of the opportunities and challenges offered by an integrated ODR system like the CRT as well as some of the steps the CRT has taken to meet these demands as transparently and collaboratively as possible. The discussion of the CRT in this article is based primarily on my experience as the tribunal's chair. While I have endeavoured to examine objectively some of the CRT's challenges and criticisms, my perspective is necessarily shaped by my ongoing involvement in the project.

\section{GENERAL COMPARISON OF PUBLIC AND PRIVATE ODR PROCESSES}

Until the CRT's implementation, ODR systems were primarily private or non-profit projects (collectively referred to as "private ODR systems"). ${ }^{15}$ By necessity, much of the quite extensive academic

8 BC Stats survey, commissioned by the BC Ministry of Justice, conducted in March 2015, confidence interval of $+/-$ $2.9 \%$, nineteen times out of twenty.

9 Ab Currie, The Legal Problems of Everyday Life: The Nature, Extent and Consequences of Justiciable Problems Experienced by Canadians (Ottawa: Department of Justice Canada, 2007) at 2, 10-12.

10 Action Committee, supra note 2 at page iii. Noel Semple, "The Cost of Seeking Civil Justice in Canada" (2016) 93:3 Canadian Bar Review 639.

11 Julie Macfarlane, "National Self-Represented Litigants Project: Identifying and Meeting the Needs of Self-Represented Litigants, Final Report" (2013) at 14.

12 Currie, supra note 9 at 60.

13 Strata, or condominium property, is a form of shared ownership over land. For a good overview of strata property law in British Columbia, see Mike Mangan, The Condominium Manual: A Comprehensive Guide to Strata Law in British Columbia, 3d ed (Vancouver: Strata Publishing Corporation, 2010)

14 Bill 44, Civil Resolution Tribunal Act, $4^{\text {th }}$ Sess., $39^{\text {th }}$ Leg., British Columbia, 2012 (as passed by the Legislative Assembly 30 May 2012). [Bill 44]

15 Maurits Barendrecht et al, ODR and the Courts: The Promise of 100\% Access to Justice? Online Dispute Resolution 2016 (The Hague: Hague Institute for Innovation and Law, 2016). 
work on ODR has focused on its theoretical aspects or on a comparison of ODR with either traditional public justice processes or alternative dispute resolution [ADR]. ${ }^{16}$ Other work has attempted to draw conclusions from the experience of private ODR systems and to use these conclusions to extrapolate ODR's impact on the public justice system. ${ }^{17}$ This is understandable given that ODR processes had not yet been adopted by a public justice system.

However, this article argues that the promise of ODR for increasing access to justice cannot be fully realized or assessed unless it is integrated into a public justice system, as has been done with the CRT. This view appears to be gaining traction with many in the ODR community. ${ }^{18}$ As discussed below, private ODR systems have fundamentally reconfigured the boundaries of dispute resolution. ${ }^{19}$ Their successes have inspired academics, lawyers, and technologists to reflect more broadly and creatively on how public justice processes, such as those used by courts and tribunals, operate. The exercise of viewing public justice processes from the perspective of the end user, as private ODR systems do, requires us to challenge the status quo on a foundational level and ask difficult questions. Which parts of these processes are necessary to achieve a fair resolution between the parties? Which parts are merely holdovers from a bygone age - a matter of habit rather than a necessity?

Private ODR systems have much to teach us in this regard, largely because they are created using best practices in software development, including rigorous user-experience testing. By design, the resulting dispute resolution processes are often simpler and easier to use than traditional public justice processes. ${ }^{20}$ The access to justice benefits from private ODR systems are derived from providing an alternative to, or augmentation of, public justice processes, without requiring the justice system itself to transform. To the extent that this relieves public pressure on the justice system, and makes it easier for the public to do what it needs to do, this can be seen as a social good.

On the other hand, seen through a systemic lens, the use of technology to create a buffer between public justice processes and the public they are meant to serve is problematic because it may actually create longterm impediments to justice transformation. For example, some private ODR systems have a strong document assembly component, such as Rechtwijzer 2.0. Developed by the Hague Institute for Innovation and Law (HiiL), a Dutch justice innovation organization, in partnership with that jurisdiction's legal aid society, Rechtwijzer 2.0 provided people undergoing a family breakdown with access to negotiation, mediation, and arbitration services. The ODR-based system also assembled court documents necessary to obtain a desk order divorce. ${ }^{21}$

These document assembly services simplify the process of navigating court forms by creating an accessible interface between the user and the justice system. ${ }^{22}$ A welcoming and easy-to-use interface asks the user plain language questions and then electronically completes the existing court form using the user's

16 Leah Wing \& Daniel Rainey, “Online Dispute Resolution and the Development of Theory” in Wahab et al, supra note 6, at 35 .

17 Suzanne Van Arsdale, "User Protections in Online Dispute Resolution” (2015) 21 Harv Negotiation L Rev 107.

18 Barendrecht et al, supra note 15 at $80-81$.

19 For an excellent review of some of these private online dispute resolution (ODR) systems, see generally $i b i d$.

20 An example of one of these user-friendly private ODR systems is MyLawBC (<http://www.mylawbc.com/>), a project of the BC Legal Services Society, which provides free public family law information and negotiation tools.

21 More about the Rechtwijzer 2.0 project is found here. "Rechtwijzer 2.0: Technology That Puts Justice in Your Hands," online: <http://www.hiil.org/project/rechtwijzer>. In 2017, HiiL announced that it was winding down Rechtwijzer 2.0, to be reconstituted at a later time.

22 See also A2J Author (<http://www.a2jauthor.org $>$ ), an online, cloud-based document assembly tool that allows people to, "easily complete and print court documents that are ready to be filed with the court system." A2J Author states that its software has conducted 3 million client interviews and assembled 1.8 million documents since 2005 . 
information. The user never sees these court forms until the end of the process, when the user is presented with the completed documents to take to a court or tribunal registry for filing. In providing this service, these private ODR systems implicitly acknowledge how difficult traditional court forms and processes can be to navigate for the everyday person.

Similarly, private ODR systems like Rechtwijzer 2.0 provided dispute resolution services such as mediation or arbitration, often at prices that compare favourably with court fees. ${ }^{23}$ These services create accessible alternatives to public justice processes by connecting users with expertise they could not otherwise easily find or afford. One of the key benefits of these services is that unlike in traditional public justice processes, ODR participants have some control over how and when they engage with the dispute resolution process. For example, they can decide when it is time to enlist the help of a mediator, who supports them in attempting to resolve their dispute consensually. By contrast, ADR processes tend to be "add-ons" rather than the focus of traditional public justice processes in courts and tribunals, a concept discussed more below.

Document assembly and online ADR services provide significant benefits to the user, in terms of allowing them to augment or avoid traditional public justice processes. However, they do little to transform existing public justice processes. Rather, by creating a buffer around the justice system, these private ODR systems may insulate the justice system from well-founded pressure from the public to transform their processes to better meet public need. Justice system transformation requires more than simply limiting direct interactions with existing processes.

Rather, it demands a fundamental reassessment and reconfiguration of public justice processes. This is not to minimize the value of private ODR systems, which have had a powerful impact on the way we think of dispute resolution in the modern age. Evolved from e-commerce ${ }^{24}$ or non-profit dispute resolution, ${ }^{25}$ many private ODR systems have demonstrated that ODR is not only possible but can also be used successfully in a number of contexts. For example, the Rechtwijzer 2.0 software, described above, was built on the Modria platform to assist people in collaboratively obtaining a desk-order divorce. The same combination of technology is also being used to resolve landlord-tenant disputes. ${ }^{26}$ The Modria platform evolved from technology used to power dispute resolution for e-commerce giants PayPal and eBay.

These private ODR systems have operated as a kind of incubator, where ideas and methods can be explored and refined. However, while there are similarities between private dispute resolution and public dispute resolution, their requirements are also different in key ways, as the CRT's development has illustrated. For example, private ODR systems can self-select their users. In the context of e-commerce disputes, this means that 100 percent of users come to the ODR system willing and able to access technology. However, public justice system processes must ensure that everyone can participate, with all of their unique attributes and challenges. This will likely mean creating ancillary offline processes to accommodate the general population, even though this adds cost and complexity. For example, despite the high adoption of online technology in British Columbia, between 3 percent and 5 percent of people do not use the Internet. ${ }^{27}$ It is therefore necessary for the CRT to provide access to services through mail or telephone, despite the tribunal's focus on online service delivery. Similarly, public justice processes should, and often must, accommodate the needs of people with literacy or language issues, visual, hearing, or other impairments, and mental health issues. The CRT works with community advocates to

23 Barendrecht et al, supra note 15 at 55.

24 See e.g. "Modria: Expanding Access to Justice with Online Dispute Resolution," online: $<$ http://modria.com/about-us $>$.

25 See e.g. the University of Montreal's Cyberjustice Laboratory, online:

$<$ http://www.cyberjustice.ca/en/laboratoire/presentation/>.

26 Barendrecht et al, supra note 15 at 39.

27 BC Stats, supra note 8. 
accommodate these needs in a variety of ways, including specialized training for staff and providing additional resources and support for people with barriers.

Further, private ODR systems can devise their own internal rules, including evidentiary and procedural ones, without being bound by the weight of the common law. This is not the case for public ODR systems, which must gingerly design technology that carefully navigates and respects applicable legal principles and statutory provisions. In the CRT context, applying the requirements of administrative law to the architecture of a software system presents some challenges. The common law adds layers of complexity that likely seem superfluous or inefficient to a software designer. For example, administrative law requires that people have the right to be heard, even though it might be more efficient from a data processing and storage perspective for a software program to impose a character limit on submissions. Private ODR systems can render themselves immune from these issues through the judicious use of business rules and system architecture.

Further, while marketing and conversion are necessary to build awareness and adoption of private ODR services, the use of private ODR services is voluntary and lies outside the justice system. For this reason, private ODR systems are not charged with the daunting task of leading the considerable change management required to transform existing public justice processes. As discussed above, the common law legal tradition, and those who act within it, tend to resist change. Lawyers, by training or temperament, skew towards pessimism. ${ }^{28}$ The unwillingness of some legal professionals to think creatively and openly about justice system reform is a significant impediment to resolving the access to justice crisis in Canada and a primary reason why public justice processes appear stagnant and outdated to many members of the public.

The freedom to act decisively, and to target particular demographics and issues, has allowed private ODR systems to thrive. They have proved that ODR is full of potential, not just for highly repeatable claims like e-commerce transactions, but also for more complex disputes like those involving marital breakdown and landlord-tenant issues. The next step for ODR is to test the theory that it can significantly reduce access to justice barriers in the context of public justice processes. This is the challenge and the opportunity of the CRT.

\section{BRITISH COLUMBIA AS AN ODR EARLY ADOPTER}

As a discipline, ODR is young, and in that context, its history in British Columbia is storied. The BC Ministry of Justice began exploring the use of ODR in a public justice context in 2011. ${ }^{29}$ That year, Consumer Protection BC, a not-for-profit corporation for the protection of consumers and marketplace fairness, began using a Modria-based ODR system to resolve disputes between consumers and businesses. ${ }^{30}$ The same year, an administrative tribunal, the BC Property Assessment Appeal Board [PAAB] began using a similar system to resolve disputes about residential property tax assessments, in conjunction with more traditional modes of administrative law dispute resolution. ${ }^{31}$ While uptake was

\footnotetext{
28 Catherine Gage O'Grady, “Cognitive Optimism and Professional Pessimism in the Large-Firm Practice of Law: The Optimistic Associate” (2006) 30 L \& Psychology Rev 23.

29 Darin Thompson, "The Growth of Online Dispute Resolution and Its Use in British Columbia" (Paper presented to the CLEBC Civil Litigation Conference 2014) at 1.1.4.

30 Consumer Protection BC, online: $<$ https://www.consumerprotectionbc.ca/odr $>$.

31 Property Assessment Appeal Board, online: < http://www.assessmentappeal.bc.ca/Resources/ODRHelp.aspx>
} 
initially low for both programs, user satisfaction and resolution rates were encouraging, and these initiatives have become permanent components of both organizations. ${ }^{32}$

The results from these forays into ODR in a public context prompted the BC Ministry of Justice to consider its application more broadly. In 2012, the BC government passed the Civil Resolution Tribunal Act [CRTA] with the goal of using technology and ADR to increase access to justice for British Columbians with small claims and condominium property disputes. ${ }^{33}$ The $C R T A$ provides that the mandate of the CRT is to provide "accessible, speedy, economical, informal and flexible" dispute resolution services for small claims and condominium property disputes. The CRT's role is to use electronic communication tools to facilitate the resolution of disputes by consent, where possible, and by decision, where necessary. The CRT is required to accommodate the diverse needs of participants wherever it can and to recognize any relationships between the parties that will likely continue after the tribunal proceeding is concluded.

While the CRT was originally planned as a voluntary tribunal, there was strong demand from condominium property stakeholders to make the CRT mandatory for all parties. In their view, a voluntary scheme would allow one party to veto the other's ability to use an accessible dispute resolution forum like the CRT. This would force the initiating party to use the Supreme Court of British Columbia (BC Supreme Court), which prior to the CRT, was the main forum for resolving condominium property disputes. In response to these concerns, the CRTA was amended in 2015 to designate the CRT as the mandatory forum for condominium property and most small claims disputes in British Columbia. ${ }^{34}$ The CRT is not the end of the road for ODR in British Columbia. Rather, it is a foothold, benefiting from earlier initiatives from $\mathrm{PAAB}$ and Consumer Protection $\mathrm{BC}$ and clearing the path for other tribunals and public justice processes to incorporate ODR, early dispute resolution, and public-focused design.

\section{WHY THE CRT?}

A question that arises from time to time is why the BC Ministry of Justice chose to establish the CRT as an independent tribunal rather than simply removing condominium property claims from the $\mathrm{BC}$ Supreme Court and placing them within the Small Claims Court. One answer is that, as a new entity with no established culture or processes, the CRT was less constrained in pioneering a transformative approach to delivering justice services to the public. The transformative potential of the CRT is that it starts from the principle of putting the public first, while also giving effect to the time-honoured tenets of fundamental justice that are foundational to our legal system. Using these principles, the CRT envisions a dispute resolution process that empowers people to become actively engaged participants in their justice system.

As the Action Committee makes clear, Canadian court processes have become increasingly onerous. Civil court matters require citizens to finance court and legal fees, take time off work, and pay for additional childcare. In 2015, the average two-day civil trial in Canada cost an average of $\$ 31,330$ in legal fees. ${ }^{35}$ Meanwhile, the average Canadian family earned a median after-tax income of $\$ 53,500$ in $2013 .{ }^{36}$

Thompson, supra note 29 at 1.1.4.

CRTABill 44, supra note 14.

34 Bill 19, Civil Resolution Tribunal Amendment Act, 4th Sess., 40th Leg., British Columbia, 2015 (as passed by the Legislative Assembly 21 April 2015).

35 Michael McKiernan, "The Going Rate" Canadian Lawyer (June 2015), online: < http://www.canadianlawyermag.com/author/michael-mckiernan/the-going-rate-2913/>.

36 Statistics Canada, Canadian Income Survey 2013, online: <http://www.statcan.gc.ca/daily-quotidien/150708/dq150708beng.htm>. 
Not surprisingly, 90 percent of parties in British Columbia's Small Claims Court are self-represented. ${ }^{37}$ Even if they could finance legal fees, many British Columbians in remote communities must travel great distances to a courthouse, burdening them with further costs. No matter where you live or who you are, navigating the civil justice system, even Small Claims Court, can be stressful and overwhelming, and there is little support available to help with the process.

This stress is compounded by increasing delay in the system. Small claims cases in British Columbia can take up to twelve months to be heard, ${ }^{38}$ while condominium property disputes in the BC Supreme Court may take even longer. These delays are costly, not just in terms of time and money, but also in terms of their effects on the health and emotional well-being of participants and on the public's confidence in the administration of justice. ${ }^{39}$ Moreover, the high cost of accessing civil justice services is not proportionate to their outcome. After all the time and money expended on a court case, less than 3 percent of BC Supreme Court civil cases actually go to trial. ${ }^{40}$ Similarly, in the rest of Canada, the United Kingdom, and the United States, 98 percent of filed civil claims do not go to trial. ${ }^{41}$ Research shows that, while some cases settle, many are abandoned because people run out of time, money, or energy without resolving the underlying dispute. ${ }^{42}$ When trials do occur, they tend to follow one-size-fits-all processes, with little mediation or case management applied to resolve disputes early.

To be clear, the identification of procedural problems with the resolution of civil disputes is not a critique of our conscientious and committed judiciary and court registry staff in British Columbia. Access to justice issues are endemic to the larger Canadian civil justice system. As George Strathy said on being sworn in as Chief Justice of Ontario, "[w]e have built a legal system that has become increasingly burdened by its own procedures, reaching a point that we have begun to impede the very justice we are striving to protect." 43 In the areas of jurisdiction under the CRT, these procedural and cost burdens are clear. Before the CRT began accepting condominium property claims in July 2016, these claims had to be resolved by the Supreme Court of BC. This required the parties to invest financially and emotionally in protracted disputes with neighbours who share a common living space. Condominium property claims often involve highly emotional conflicts over matters with a relatively low monetary value - for example,

37 BC Judges Compensation Commission, "Final Report of the 2010 British Columbia Judges Compensation Commission" (2010) at 19 .

38 "Semi-Annual Time to Trial Report of the Provincial Court of British Columbia (30 September 2015) at 13-15.

39 Macfarlane, supra note 11 at 14.

40 British Columbia Justice Reform Working Group, “Effective and Affordable Civil Justice,” Report of the Civil Justice Reform Working Group to the Justice Review Task Force (2006), n 3, online: < http://www2.gov.bc.ca/assets/gov/lawcrime-and-justice/about-bc-justice-system/justice-reform-initiatives/cjrwg_report_11_06.pdf >.

41 For US trial rates, see Brian J Ostrom \& Neal B Kauder, Examining the Work of State Courts, 1997: A National Perspective from the Court Statistics Project (Washington, DC: Bureau of Justice Statistics, 1998) at 11. See also John Barkai, Elizabeth Kent \& Pamela Martin, "A Profile of Settlement” (2006) 42 Court Review 34 at 34-35. For Canadian civil trial rates, see e.g. Canadian Centre for Justice Statistics, Civil Courts Study Report (Ottawa: Minister of Industry, 1999) at 10. For UK civil trial rates, see UK Ministry of Justice, Court Statistics Quarterly: October to December 2012 (London: Ministry of Justice, 2012) at 2.

42 Carl Baar, "The Myth of Settlement" (Paper presented to the Annual Meeting of the Illinois Law and Society Association, 28 May 1999) at 12. For some of the difficulties in collecting data on this issue, see Canadian Forum on Civil Justice (CFCJ), Civil Non-Family Cases Filed in the Supreme Court of BC: Research Results and Lessons Learned, (Victoria: Focus Consultants for the CFCJ, 2015).

43 Paola Lorrigio, “Ontario's Legal System Too Costly and Complicated, New Chief Justice Says," Globe and Mail (9 September 2014), online: <http://www.theglobeandmail.com/news/national/ontarios-legal-system-too-costly-andcomplicated-new-chief-justice-says/article20506719/>. 
parking spots, pets, rentals, and the use and repair of common property. For the vast majority of condominium owners, taking such a claim to a superior court is not worth seriously considering.

Despite this, it is clear that entrenched conflicts tear at the fabric of these small condominium communities across the province. Over one million British Columbians live, own, or work from condominium properties, and, until the advent of the CRT, they had no accessible dispute resolution forum. ${ }^{44}$ For condominium disputes, early and collaborative dispute resolution is essential to cultivate a respectful and positive communal living environment.

\section{HOW DOES THE CRT WORK?}

The Action Committee recommended that the civil and family justice system be reformed to avoid, manage, and resolve disputes in ways that are as timely, efficient, effective, proportional, and just as possible:

- by preventing disputes and by early management of legal issues;

- through negotiation and informal dispute resolution services; and

- where necessary, through formal dispute resolution by tribunals and courts. ${ }^{45}$

This is what the CRT aims to achieve. The CRT involves four stages, each part of a seamless, end-to-end process focused on early, participatory ODR. Before beginning a claim with the CRT, a person with a dispute can access a free online tool called the Solution Explorer, which uses guided pathways to help a person learn more about their dispute so that they can make informed choices about how to resolve it. ${ }^{46}$ The Solution Explorer asks a series of questions about the dispute and then provides information and resources tailored to that dispute. For example, someone contesting a condominium bylaw fine might be given information about the applicable provisions of the Strata Property Act as well as a template letter to edit and send to their condominium council. ${ }^{47}$ At the end of the pathway, the Solution Explorer provides a summary of the person's claims as well as recommended resources and next steps.

If someone is not able to resolve their dispute using the Solution Explorer, the next step is to start a CRT claim, using the online intake process. A key design feature of the CRT is that, wherever possible, a user should only have to enter information once, and the system should carry this information forward to other stages of the CRT process. Finally, the CRT process incorporates relevant parts of the tribunal's rules on an as-needed, when-needed basis, to avoid overwhelming parties with inapplicable rules. After serving the others in the dispute with notice of the claim, the parties have a brief opportunity to negotiate directly with each other. While the parties will be given some resources to help them do this, this is a low intervention area for the CRT. The intention is to resolve a modest number of "easy" disputes very early and very inexpensively so that the parties can move on with their lives. If negotiation is not successful, the parties will enter a facilitation phase where an expert facilitator will help the participants to reach a consensual agreement. The facilitator can use a variety of communication channels to work with the parties, including the CRT platform, email, text, phone, video conferencing, fax, and mail. Despite being online, the CRT is a very human-driven organization. Leveraging technology, the CRT democratizes

44 BC Ministry of Housing, "Strata Housing," online: <http://www2.gov.bc.ca/gov/content/housing-tenancy/stratahousing>.

45 Action Committee, supra note 2 at 2.

46 To use the CRT Solution Explorer, see Civil Resolution Tribunal, online: $<$ https://www.civilresolutionbc.ca/self-help/>.

47 SBC 1998, c 43. 
access to dispute resolution services by connecting the public, wherever they may live, with expert facilitators and tribunal members.

The CRTA provides for an extremely flexible and responsive facilitation phase, enabling the facilitator to use a variety of tools to help the parties settle their claims. The facilitators are generally not lawyers, although they can be. Rather, facilitators must have strong mediation experience and skills. The focus at this stage is on helping the parties to reach a consensual agreement, wherever possible. Facilitators may help parties settle all or some of the issues, and they can caucus with a party to provide a frank evaluation of the dispute. Settlement communications in the facilitation phase are confidential and are not disclosed to the tribunal members. If the parties reach an agreement, the facilitator can ask a tribunal member to convert the agreement into a binding order of the tribunal, which can be enforced in court, without the parties having to sue for a breach of the agreement.

The CRT anticipates that the facilitation phase could resolve up to 70 percent of disputes. ${ }^{48}$ In the event that the parties are unable to reach an agreement, the facilitator's role includes preparing the parties for adjudication by helping them, in a neutral way, to narrow issues and organize their claims. The dispute is then transferred to a tribunal member, a lawyer with specialized expertise in small claims or condominium property matters, who hears the parties' arguments (usually in written form), considers the evidence, and then issues a binding decision of the tribunal, which is emailed or mailed to the parties. If an oral hearing is necessary, due to credibility issues, for example, this is conducted though telephone and video conferencing. The CRT's adjudicative process is very similar to that of other large administrative tribunals, and, of course, tribunal members are subject to the same procedural fairness requirements that govern administrative tribunals generally. ${ }^{49}$

The civil justice system struggles with proportionality, and the principle is often framed in opposition to fairness. However, the Supreme Court of Canada has recently endorsed the proportionality principle, finding that "a process can be fair and just, without the expense and delay of a trial, and that alternative models of adjudication are no less legitimate than the conventional trial. This requires a shift in culture ... [t]he proportionality principle means that the best forum for resolving a dispute is not always that with the most painstaking procedure."

From beginning to end, the CRT process is intended to take about ninety days for most cases, and the average total cost to the parties is roughly the same as in Small Claims Court, or about \$200. However, many parties will pay less than at Small Claims Court because fees are staged so that parties who resolve their disputes early pay less than those who require the full range of the CRT's services. Like the Small Claims Court, there are fee exemptions for those experiencing financial hardship, and the CRT has worked with community legal advocates to design an accessible process for people who need these exemptions. The CRT's fees are meant to reflect the proportionality principle; they are high enough to deter frivolous claims, but not so high that they are unbalanced with the interests at stake.

\footnotetext{
48 This estimate is based on experiences from programs such as the Court Mediation Program for small claims disputes in British Columbia. For general success rates for mediation, see e.g. US Department of Justice, "Statistical Summary: Use and Benefits of Alternative Dispute Resolution," online: <http://www.justice.gov/olp/adr/doj-statistics.htm>, which found a success rate for voluntary alternative dispute resolution of $71 \%$ in 2015 .

49 Baker v Canada (Minister of Citizenship and Immigration), [1999] 2 SCR 817.

50 Hryniak v Mauldin, 2014 SCC 7 at 27-28.
} 


\section{WHERE IS THE CRT NOW?}

On July 13, 2016, the CRT began accepting condominium disputes. About a year later, on June 1, 2017, the CRT assumed jurisdiction of small claims disputes \$5,000 and under. The monetary threshold for claims within the CRT's jurisdiction will slowly increase, by regulation, until the CRT becomes the mandatory forum in British Columbia for claims under \$25,000. Consistent with the CRT's public-focused approach, the next phases of the technology development, namely expanding the case management system and the CRT's communication tools, will be informed by feedback from the CRT's early participants. In fact, in the first forty-eight hours after beginning to accept claims, the CRT made agile and transparent changes to the CRT's website, processes, rules, and intake form in response to feedback from participants. Continuous improvement is a core value for the CRT, and this improvement involves consulting with the public, testing processes with stakeholders, listening closely, incorporating feedback, and then doing all of this again and again.

\section{A. Opportunities and Challenges}

The combination of technology and early dispute resolution presents an exciting opportunity to rebuild public justice processes around the needs of the public and truly realize the long-held promise of ODR. However, the integration of ODR systems into a public justice process presents opportunities as well as challenges. The most significant of these are summarized below, along with the CRT's approach to navigating them. Briefly canvassed here, each of these issues would be a fruitful area for further study in the future.

\section{B. Opportunities}

\section{Leveraging Access to Technology to Increase Access to Justice}

Online technology is not a panacea. Dogmatic insistence that technology can resolve any problem ignores the fact that it is only one tool within a varied kit. At times in the CRT's development, in answer to a need that online technology will not easily accommodate, someone will eventually say: "Why not just pick up the phone in those cases?" which often turns out to be the most efficient and sensible solution to an intractable technology problem. Requiring technology to resolve all problems often results in unnecessarily complex processes, which is, ironically, one of the justice system ailments that ODR is meant to address. Despite its limitations, technology is able to offer a relatively inexpensive, nearly universal way of connecting people with expertise, support, and, most importantly, other people. Among British Columbians aged eighteen to thirty-four, smartphone ownership is nearly universal - 93 percent and it is 74 percent for those aged thirty-five to fifty-four. ${ }^{51}$ Ninety-three percent of British Columbians have broadband connectivity. ${ }^{52}$

Online technology also offers a high degree of comfort, convenience, and familiarity, at least within the scope of common online activities. A recent BC Statistics survey found that 92 percent of British Columbians use the Internet daily, including 69 percent of people over the age of seventy-four. ${ }^{53}$ British Columbians are overwhelmingly comfortable with using email (94 percent), searching for information or services (91 percent), texting (89 percent), and online banking (80 percent) ${ }^{54}$ Given recent studies about

\footnotetext{
51 Insights West, “Smartphone Insights,” online: <http:/www.insightswest.com/wpcontent/uploads/2014/07/Rep_InsightsWest_iamota_SmartphonesForiamota_26June2014_ForWebsite.pdf $>$.

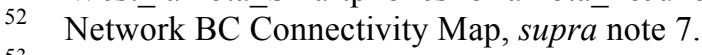

53 BC Stats, supra note 8.

54 Ibid.
} 
the public's challenges in using the court system, it is reasonable to conclude that British Columbians access the Internet much more easily and comfortably than they do traditional justice institutions and processes. $^{55}$

While the overwhelming majority of citizens have access to online technology, any truly accessible justice system must also consider and address the needs of the minority. What about people who are unable or unwilling to use the CRT's online platform? In such cases, the tribunal will assist a party with information and support in using the CRT online. However, where a party has significant barriers to using the online platform, the CRT provides telephone-based or paper-based services. This is consistent with the CRT's stated commitment to build the tribunal around people, by assisting them to resolve their disputes using the communications method that best serves their needs.

\section{Transforming Public Justice System Processes}

By integrating the CRT with the existing justice system, the CRT model has the opportunity to fundamentally transform the justice system rather than simply augmenting or "alternativizing" it. As discussed above, some programs that aim to increase the use of ADR in the justice system operate as "addons," augmenting the existing process but never really challenging the justice system's focus on a "day in court," which is treated as inevitable, despite its rarity. Similarly, as discussed above, despite their clear benefits to users, private ODR or ADR systems may externalize the cost and responsibility for justice system reform away from the government and the justice system. The "alternativizing" of the justice system relieves public justice processes of the responsibility to reform and modernize to better meet the public's need.

By integrating with the justice system, the CRT model provides a template for how transformation and innovation can occur in a public justice context. The CRT model goes beyond incremental measures, such as simply changing forms or allowing online filing. Rather, it inverts the traditional public justice process model by assuming that disputes can be resolved consensually, with the right assistance and expertise. The CRT model, therefore, builds processes aimed at supporting this approach. The goal is to provide a seamless, simple, end-to-end ODR process that is both fair and convenient for the public. Once established, the CRT model could be adapted and applied to a wide variety of disputes. The model is likely particularly useful where (1) there is a high number of participants who cannot afford legal representation; (2) the parties have an interest in building or maintaining relationships; and (3) existing public justice processes are highly complex or time consuming. Family disputes, for example, fit these requirements and would likely benefit from the CRT model. The Rechtwijzer 2.0 platform, and its BC iteration, MyLawBC, are good examples of the potential for using ODR in the context of family disputes. Whereas the Rechtwijzer 2.0 process stopped outside the courthouse doors, an integrated approach would spare families the time and inconvenience of any court process by connecting the ODR system with a binding adjudicative component, whether offered by a court or tribunal.

\section{Co-Designing Justice Processes with the Public}

The CRT is the first known area of the Canadian justice system that has been co-designed with the public. At every stage of the CRT's development, from the Solution Explorer, to the intake system, to fee exemptions, the CRT has worked with the public and key stakeholders, like community legal advocates, to make sure the CRT meets their needs. The CRT's software has been, and continues to be, developed

\footnotetext{
${ }^{55}$ See e.g. Action Committee, supra note 2; Macfarlane, supra note 11.
} 
using an agile process that focuses on incrementally producing functional, user-tested software that works for the public. ${ }^{56}$

Typically, CRT user testing starts with people who experience multiple barriers to accessing justice as well as with the people who support and advocate for them. The assumption is that if a CRT process or technology component works for vulnerable people with barriers, it will likely be accessible to the wider public. Generally, the CRT's next step is to recruit public testers who are representative of expected users - for example, people who have had a previous small claim or condominium problem. After each round of testing, the CRT reviews the feedback and makes improvements. One of the most important ways the CRT has built goodwill and trust with stakeholders is to report back after each consultation or testing activity. For example, after asking for public input on CRT fee options and the CRT's draft rules, the CRT published a blog post reporting on public feedback and explaining how the tribunal was going to apply this information. 57

This commitment to early public co-design has generated very positive results at later stages of user testing. For example, after several rounds of early user testing for the Solution Explorer, including observational user testing, ${ }^{58}$ the CRT team launched a closed beta test, where members of the general public tested the system and completed a survey. This survey yielded a tremendous amount of valuable constructive feedback. ${ }^{59}$ It also validated the general approach to the Solution Explorer. About 90 percent of respondents said the technology worked well and that it was easy to use, while 94 percent said the information was accurate. This overall feedback supports the theory that public co-design produces public justice processes that closely match public need and expectations.

\section{Normalizing the Integration of Plain Language in the Justice System}

To be widely understood, general information for the public must be written at a grade 6 reading level. ${ }^{60}$ Despite this, public legal information and court and tribunal forms routinely use complex language and "legal-eze" that assume a high degree of facility in English. Part of the CRT's commitment to putting the public first includes truly ensuring that CRT information and forms are as simple and clear as possible. The CRT has worked extensively with public legal education and information providers, as well as community legal advocates, to ensure that the CRT's platform, language, forms, rules, and processes are accessible. Part of this endeavour includes providing some information in video or audio format for those who have difficulty absorbing written information and finding alternative ways to support participants for whom English is not a first language, including by offering free telephone interpretation services.

56 For more on the agile approach to software development, see James Shore \& Shane Warden, The Art of Agile Development (Sebastopol, CA: O’Reilly Media, 2008).

57 See e.g. Shannon Salter, "What You Told Us about the CRT Rules," online: Civil Resolution Tribunal < https://civilresolutionbc.ca/new-crt-rules/ >

58 The Civil Resolution Tribunal (CRT) conducted observational user testing by inviting members of the public with strata disputes to come to the CRT office and try the system while CRT staff recorded how they used it (with their consent). This yielded some surprising results for the team. Some features that the CRT team was convinced would be invaluable were merely annoying and confusing for users. These features have been removed or changed.

59 The lessons from this constructive feedback could easily fill another article. Overall, the CRT team learned that lawyers and information technology professionals are not always good at gauging how members of the public with legal problems will behave online. Public testing led us to remove or de-emphasize features that turned out to impede people's access to information and increase the ease with which people can navigate forward and backward in their use of the software.

60 Keenan J. Safeer, "Health Literacy: The Gap between Physicians and Patients" (2005) 27 American Family Physician 463. 
Technology can assist this objective in a number of ways. For example, information from a person's Solution Explorer exploration is used to present them with a more tailored CRT application form, which already contains some basic information about their problem, based on their answers in the Solution Explorer. The form itself asks as little information as possible to allow the CRT to process the claim. Wherever possible, the application form fills in information automatically. For example, if a person begins to type an address, the rest of the address is filled in for them, minimizing incorrect information. Similarly, if someone misses a field, the application form will remind them of this omission before letting them continue, reducing possible delays that may result from later requests for this information.

\section{Challenges}

Many of the opportunities afforded by a CRT model stem from the "newness" of the initiative and the absence of any established procedures or rules, aside from those that apply to administrative tribunals generally. However, the CRT's newness also presents some significant challenges that require a great deal of careful thought, collaboration, and patience to navigate successfully.

\section{Fear of Change}

One of the fundamental concerns voiced by the legal community when the CRT was first announced was that it would subvert foundational legal principles by replacing courts with "robojustice." A common myth about ODR is that it relies on algorithms and avatars to decide disputes. This can be frightening, particularly to justice system actors who worry that fairness and the rule of law will be sacrificed in the name of efficiency. While some software programs, such as IBM's Ross, or Canada's own Blue J Legal are using artificial intelligence $[\mathrm{AI}]$ to build access to legal information and conduct basic legal research, ${ }^{61}$ most ODR platforms rely on a combination of basic AI and good old-fashioned human skill and judgment. For example, the Solution Explorer uses simple AI by providing guided pathways to lead people to tailored legal information and tools. ${ }^{62}$ However, the facilitation and adjudication phases of the CRT are conducted by humans with extensive dispute resolution skills, either in ADR or administrative decision making. In ODR, technology is used to connect the public to highly skilled humans and does not replace them with robots.

The corollary fear is that technology will render lawyers obsolete. The CRT is being implemented at a time of considerable change and tumult in the legal profession, in part due to the profession's reluctance to modernize its provision of legal services to the public. ${ }^{63}$ With the intention of evening the playing field for participants, the CRTA creates a rebuttable presumption of self-representation. ${ }^{64}$ This was not popular with lawyers, who sometimes felt they were being excluded. ${ }^{65}$ The issue of change management in public justice reform initiatives is important, because the failure to engage and communicate properly with stakeholders can quickly scuttle otherwise sound initiatives. The CRT undertook a considerable change

61 Ian Mulgrew, "Siri for Lawyers? Artificial Intelligence on Cusp of Changing the Legal Profession," Vancouver Sun (22 June 2016), online: < http://vancouversun.com/opinion/columnists/ian-mulgrew-siri-for-lawyers-artificial-intelligenceon-cusp-of-changing-the-legal-profession >. See also, Blue J Legal, online: < https://www.bluejlegal.com/>

62 Darin Thompson, "Creating New Pathways to Justice Using Simple Artificial Intelligence and Online Dispute Resolution” (2015) 2 Intl J Online Dispute Resolution 1.

63 Richard Susskind \& Daniel Susskind, The Future of the Professions: How Technology Will Transform the Work of Human Experts (Oxford: Oxford University Press, 2015); Jordan Furlong, "Do Law Differently: Futures for Young Lawyers," CBA Futures Initiative (2016).

64 Bill 44, supra note 14 at s.20

65 Cristin Schmitz, “Tribunal Aimed at Streamlining Deals Out Lawyers, Prompting Ire,” Lawyers Weekly (3 April 2015), online: <http://www.lawyersweekly.ca/articles/2351>. 
management project to engage with stakeholders, including the public, the condominium community, community legal advocates, lawyers, mediators, and the courts. The CRT conducted public forums around the province to consult with the public. The CRT website offers continuous updates and requests for public feedback. The CRT also established a number of working groups to gain input from various stakeholders. In many cases, the CRT met with particular organizations over a period of time to try to address concerns and gain understanding. The most important tools in this project were open, frequent communication, and a willingness to compromise, where doing so could build consensus without undermining the CRT's access to justice mandate.

\section{Assumptions about Dispute Resolution Processes}

In addition to the assumption that a public ODR system will replace lawyers with robots, the CRT has frequently encountered assumptions about the efficacy of ODR-based dispute resolution processes as well as comparisons between ODR and more traditional court processes.

\section{(a) Assumptions about ADR}

Within the ADR community, there are strongly held views that the effectiveness and accountability of processes like mediation and facilitation lie in their format. That is, ADR is ineffective if, for example, participants are not in the same room, if they cannot see each other's body language, or if they have not engaged in pre-mediation conferences. ${ }^{66}$ For some, the idea that mediation can occur at a distance or over email, or that ADR services can be scaled down or up to meet the needs of the parties and the issues, rather than delivered as a full package, is anathema.

However, for many people, mediation services are almost as unaffordable or inaccessible as legal services. Both services can suffer from some of the same access to justice barriers including high rates, travel costs, time away from work and family, and uncertain outcomes. Distance mediation, using technology such as video and telephone conferencing, can reduce many of these barriers in the same way that technology reduces access to justice barriers generally. Further, studies on distance mediation suggest it compares favourably with in-person mediations, both in terms of the number of settlements and the participants' opinions about its efficacy ${ }^{67}$ In some contexts, distance ADR processes may actually have advantages over in-person ones. Antagonistic body language, for example, may discourage settlements. Participating comfortably in one's home may reduce anxiety or logistical hurdles for those with mental health issues or physical disabilities. The scholarship in this area is nascent, and the CRT will be closely monitoring and analyzing which techniques seem to be most effective in different contexts and will continuously improve in this area.

\section{(b) Assumptions about adversarial processes}

Justice system actors often hold certain assumptions about common law justice processes that can impede the development of public ODR systems. The most powerful of these is that the adversarial system, and its attendant focus on in-person testimony and cross-examination, is the ideal form of dispute resolution. The idealization of the adversarial trial process can cause deep scepticism about ODR systems

66 See e.g. Joseph Goodman, "The Pros And Cons of Online Dispute Resolution: An Assessment of Cyber-Mediation Websites" (2003) 4 Duke L \& Tech Rev 3. For a discussion of the "accountability problem" in online mediation, see Orna Rabinovich-Einy, “Technology's Impact: The Quest for a New Paradigm for Accountability in Mediation" (2006) 11 Harv Negotiation L Rev 253.

67 Catherine Tait, "Evaluation of the Distance Family Mediation Project: Report on Phase III of the Technology-Assisted Family Mediation Project" (March 2013), online: <http://www.mediatebc.com/PDFs/1-2-Mediation-Services/DistanceFamily-Mediation-Evaluation-Report-FINAL.aspx>. 
like the CRT, which focuses heavily on consensual dispute resolution and, failing that, uses the flexibility enjoyed by most administrative tribunals to make the adjudicative process as accessible and fair as possible. There is no doubt that adversarial processes are sometimes necessary and have an important role, especially in criminal and public interest trials, in testing evidence and holding state authority to account.

However, an examination of public justice processes in civil cases demonstrates that, as a dispute resolution mechanism, adversarialism is less than ideal in several regards. First, civil justice processes focus on preparing for an adversarial trial - the day in court. This forces parties to expend a great deal of time and money on preparing pleadings, undertaking discovery, bringing preliminary motions, and participating in trial scheduling conferences. While establishing one's case can, at times, assist parties in reaching a settlement, these activities are wasted in many of the approximately 98 percent of filed civil claims that never make it to trial. Further, this focus on adversarial pre-trial activities tends to entrench the parties' positions from the outset, wedding parties to positions rather than interests, and making it difficult to reach consensual agreements. This is especially problematic given that parties tend to be happier with consensual resolutions rather than judicially imposed resolutions. ${ }^{68}$

Second, social science evidence increasingly suggests that some of our assumptions about the adversarial system's capacity to determine truth and reach sound decisions may be misplaced. Judges and tribunal members, despite their excellent training and commitment to the rule of law, have a difficult time not being human, and they inherit the heuristics that attend that proposition. ${ }^{69}$ Research suggests that, like everyone else, decision makers are susceptible to biases and weaknesses in reasoning, which sometimes affect the outcome of the cases they determine. ${ }^{70}$ Maintaining adjudication as the gold standard for dispute resolution ignores some of the limitations of human decision making. Adversarial legal processes serve as an important check on state power in criminal cases and a powerful lever for restitution in civil ones. However, minimizing the limits of adversarialism, while inflating its benefits, impairs an evidence-based approach to the design of our public justice processes. In particular, this may cause us to ignore other important considerations like proportionality, the relationship between the parties, and the parties' underlying interests in the resolution of their dispute.

\section{Government Innovation}

Seemingly every jurisdiction in the modern world is haunted by examples of government technology projects gone awry. ${ }^{71}$ High-profile technology project failures combined with frustrations with red tape, complex procurement processes, and a lack of market discipline have caused critics to proclaim that governments simply cannot innovate. ${ }^{72}$ The very debate over whether governments are capable of leading innovation initiatives is one of the challenges to implementing public ODR projects like the CRT. A

68 Austin Lawrence et al, The Effectiveness of Using Mediation in Selected Civil Law Disputes: A Meta Analysis (Ottawa: Department of Justice, 2007) at 21-23.

69 CRT tribunal members are also subject to this concern. CRT members undergo mandatory training on cultural competency, mental health issues, and implicit bias to try to counteract heuristics.

70 Eyal Peer \& Eyal Gamliel, "Heuristics and Biases in Judicial Decision-Making" (2013) 49 Court Review 114. See also Craig Jones, "The Troubling New Science of Legal Persuasion: Heuristics and Biases in Judicial Decision Making" (2013) 41 Adv Q 48; Craig Jones \& Micah Rankin, "Justice as a Rounding Error: Judicial Bias in Second Degree Murder Sentencing" (2014) 52:1 Osgoode Hall LJ.

71 See e.g. James Ball \& David Pegg, "The Costly Trail of British Government IT and 'Big Bang' Project Disasters," The Guardian (19 August 2014), online: <https://www.theguardian.com/technology/2014/aug/19/costly-trail-britishgovernment-it-disasters-universal-credit>.

72 Nikhil R Sahni "Unleashing Breakthrough Innovation in Government," Stanford Social Innovation Review (Summer 2013), online: <http://ssir.org/articles/entry/unleashing_breakthrough_innovation_in_government>. 
related ongoing debate in the ODR community is whether governments should ever be in the business of ODR system development or whether only the private sector is competent to deliver sophisticated, functioning software that meets the needs of the end user. On the other hand, private ODR systems may not always meet the needs of public justice processes, which have highly complex and often competing legal, privacy, budgetary, accessibility, and logistical demands.

To some extent, the CRT model illustrates this point. The CRT was developed using a hybrid model. The CRT's case management system is powered by an off-the-shelf customer relationship management platform called Salesforce. ${ }^{73}$ Salesforce has an established record for security, robustness, and scalability, which are all important features when managing thousands of claims and related personal information. However, Salesforce was developed for private corporations, not public justice processes. To adapt it to an ODR context, the BC Ministry of Justice contracted with local software design and development companies to create the Solution Explorer, the intake system, and the communications portal, all of which are relatively lightweight applications, built to integrate into the Salesforce platform. As a strategy for minimizing the risk of a government technology failure, buying as much as you can off-the-shelf and customizing the rest is a good starting point.

Governments also lack a key driver for private software companies to produce timely, functioning, user-focused software: market discipline. If a private software company fails to deliver a quality leadingedge product, no one will buy it, investors will pull out, and the company will be eclipsed by a new competitor. In other words, private companies must innovate or die. Governments, conversely, do not face any market discipline except, perhaps, for the distant threat of electoral defeat if the software failure is sufficiently large or outrageous. Moreover, governments are notoriously risk adverse, with a strong bias towards inaction. These are hardly the ingredients for software innovation, which requires risk taking and a "failing forward" approach to development. There is also no doubt that government initiatives, by their nature, often take more time than private ones. Delay is poison for innovation because it saps money, time, momentum, and credibility. Unfortunately, delay is also endemic to government.

In British Columbia, the CRT was conceived and championed by a committed and thoughtful group of individuals within the provincial Ministry of Justice, which saw value in an innovative access-to-justice project like the CRT and took risks to implement it. One of those risks was collaborating with the CRT to undertake early, frequent user testing on the Solution Explorer, even though the technology was not completely built, and bugs and glitches remained. This is a risky proposition for government because if the technology is not yet fully functional, there is a chance that its shortcomings could become media headlines. At the same time, a key antidote to the lack of market discipline in public sector software development is rigorous validation with users at every stage to ensure that software is meeting public need. There are ways to bridge these conflicting interests - for example, by gradually expanding the circle of testers as confidence in the basic functionality of the software grows and by carefully communicating to key stakeholders that the software is early work and their feedback will inform improvements. In short, the CRT model proves that governments can innovate, if they take a strategic, agile, collaborative, and highly disciplined approach to new projects.

\section{Technology Risk}

Thankfully, the CRT has not encountered any technology issues since beginning to accept disputes for resolution. Despite this, the team has devoted considerable time to ensuring that the CRT is able to cope with the hiccups that are part of any new technology project. The goal is to ensure that the CRT has strong risk mitigation strategies so that it can handle possible technology interruptions while still providing

73 For more, see Salesforce, online: $<$ https://www.salesforce.com/ca/?ir=1>. 
timely service to the public. A major risk mitigation strategy was deciding to build the CRT's online services on the already well-established and widely used Salesforce platform. ${ }^{74}$ This platform has been used successfully by private and public organizations much larger than the CRT, and the scale of the platform means that support and updates will be readily available in the event of a problem. Additional technology risk-mitigation strategies include temporarily reverting to telephone-based or paper-based service, triaging claims, and escalating claims to adjudication if necessary to avoid a backlog. However, the CRT's biggest risk mitigation strategy is the commitment to rigorously include the public in developing and testing processes to ensure that public needs are being met.

\section{CONCLUSION: WHAT WILL THE FUTURE LOOK LIKE?}

Putting the public first is not a one-time endeavour; it is an enduring obligation. One of the CRT's guiding principles is a commitment to continually improve by regularly asking for, and incorporating, public feedback about the CRT's processes. Technology enables an agile response both to measuring and increasing public satisfaction with the tribunal's services, which will let the CRT adapt quickly to serve the public better. The CRT will transform small claims and condominium property disputes by coupling skilled facilitators and tribunal members with new online tools to encourage accessible early dispute resolution. As the first ODR system integrated into public justice processes, the CRT will also yield valuable evidence about ODR's capacity to increase accessibility to our justice system.

If successful, the CRT model, featuring a seamless, service-driven, flexible ODR experience, could be leveraged by multiple organizations in different jurisdictions in the future. In British Columbia, these tools will be applied across the administrative justice system in the coming years, tailored to each tribunal's processes and jurisdiction. Under the $\mathrm{BC}$ government's tribunal transformation initiative, the administrative justice system, led by the CRT, will increasingly focus on using technology and early dispute resolution to increase access to justice for citizens. ${ }^{75}$ At its core, the CRT is intended to empower people to resolve their problems in a manner that respects their dignity, their autonomy, and their lived reality. ${ }^{76}$ By putting people at the centre of the dispute resolution process, rather than the periphery, the CRT will significantly increase access to justice for British Columbians and pioneer a new model for the delivery of civil justice services in Canada.

Ibid.

Ministry of Justice, "White Paper on Justice Reform - Part Two: A Timely, Balanced Justice System" (2013).

76 For more on the intersection of human dignity and administrative law, see David Dyzenhaus, "Dignity in Administrative Law: Judicial Deference in a Culture of Justification" (2012) 17 Rev Const Stud 87. 